\title{
Between the East and the West - Phenomenon of Tartar Literary Criticism in The Lingvo-Cultural Aspect
}

\section{Tagir Shamsegalievich Gilazov}

The Kazan (Privolzhskiy Federal University, 18, Kremlyevskaya Street, Kazan, 420008

Irina Sovetovna Karabulatova

The Institute of Socio-Political Research, Of the Russian Academy of Science, 32a, Leninskiy Prospect, Moscow, 119991

Flera Sagitovna Sayfulina

Chulpan Malikovna Kurakova

18, Kremlyevskaya Street, Kazan, 420008, Talipova Gulfiya Maratovna, The Affiliated Branch of the Tyumen University in Tobolsk, 58, Znamenskogo Street, Tobolsk, Tyumen Region, 626150

\section{Gulphiya Maratovna Talipova}

The branch of Tyumen University in Tobolsk 626150, Tyumen Oblast, Tobolsk, the street name Znamensky, Building 58

Doi:10.5901/mjss.2015.v6n3s2p508

\section{Abstract}

The article is devoted to research into the phenomenon of the Tatar literary critical thought in the context of evolution of the Tatar culture amidst Western and Eastern philosophies. The authors proceed from the analysis of the genesis of the Tatar literary critique and highlights bifurcation assembly points, i.e. contribution of certain authors of the early XX century (19061920) into the development of the literary critique as one of the branches of literary studies essential for the development of the literary process as a whole. The evolution of the scientific concept of the national literary critique is traced back to numerous factual materials pertaining to different types and genre of literary critical thought of such renowned national authors as S.Mardzhani, R.Fakhrutdinov, F.Amirkhan, G.Tukay, N.Dzhamal, N.Garsi, M.Ukmasi, G.Ibragimov, G.Battal, G.Sagdi, et al., who made a significant input into establishment and development of the Tartar literary critique, its methods, determination of the main principles at solving major tasks, which in its turn allows us to follow the process of fledging national literary criticism. The authors demonstrate evolution of the terminology in the Tartar literary critique under the influence of Oriental and European traditions. The authors of the article make convincing conclusions about the fact that in the beginning of the last century and under the influence of the Oriental on the one hand and Russian and European on the other, literary theory, cultural studies and at the time of serious contemplations over the literary terminology and concepts, the Tartar literary criticism paved the way for independent development, which in its turn promoted the establishment of the Tatar scientific thought and the theory of literature.

Keywords: Literary criticism, national literature, literary critical thought, Oriental, West, literary interconnections and interdependence, branch, type, genre, speech ethnography.

\section{Introduction}

At the turn of $20^{\text {th }}$ and $21^{\text {st }}$ centuries in the environment of globalization and integration of market conditions, the humanitarian thought has undergone tremendous changes, which is particularly evident in the development of national literatures. The shift of spiritual-moral as well as social-esthetical values and cultural reference points became a huge trial for the oral lore. The Tartar literature is a unique phenomenon, which has been actively evolving in the post-Soviet and inter-Russian space, providing for the growth of the national consciousness of the Tartar ethnos. The Tartars as a second ethnos in Russia managed to preserve their ethnical culture and literature (Sibgatullina, 2014; Matthew, \& Bukharaev, 2000; Sayfulina, et al., 2013; Sayflina, \& Karabulatova, 2014). This being said the researchers stress that the Tartars 
experience powerful pressures from the state-related ethnos as the result of migrations and globalization (Altan, 2003; Karabulatova, \& Polivara, 2013). In this light the issue of evaluation of contemporary state of literature and literary studies as a whole comes to the fore and that includes literary criticism, which is called upon to evaluate literary process and to pan out the ways for its future development (Barthes, 2007; Culler, 2002; Frye, 2000; Eagleton, 2002).

Literary critic Sayfulina F. noted as a positive trend for the development of the contemporary literary critique the presence of the discussion groups, round tables on various current issues of Tartar literature and critique organized by the editorial office of "Kazan Utlary" ("The Lights of Kazan", Kazan) magazine, which goes back over 90 years ago. She remarked that "it is this magazine that is the mouthpiece for a critic to voice his opinion about developments in the contemporary tartar literary process as well as to speak out in relation to the history of its evolution as a whole and of its parts in particular" (Sayfulina, \& Yakupova, 2014). Furthermore literary critic A.Zakirzyanov upon analysing numerous materials of literary critique published in the periodicals, describes the state of the literary critique of the second half of 1980-1990 as being in the state of "crisis" (Zakirzyanov, 2011).Despite the fact that the literary critique of the early $21^{\text {st }}$ century shows some positive shifts, on the whole however it has not climbed out of stagnation and failed to claim a commendable spot in the global literary process.

Today the scientists are particularly interested in the process of active formation and effective development of the Tartar literary criticism in the beginning of the $20^{\text {th }}$ century (1906-1913) in terms of the similarities of the socio-political state, when the national critique forms and evolves as an independent science and acquires apart from the literaryesthetical function also socio-national and spiritual-ethical role. In this period the literary criticism as one of the areas of speech ethnography does not just merely uncovers the constants of the Tartar culture to the reader, it also forms selfconsciousness of the Tartar intellectuals having an impact in doing so over the evolution of the Tartar ethnos as a whole. In our view the Tartar literary criticism of the early $20^{\text {th }}$ century is valuable not just as historical canvas to evaluate the literary process of the time, it is also significant to objectively assess the modern state of the criticism, in order to "revive" it and to set out correctly the outlooks for its future development. And this is why this research is so relevant and novel.

The Tartar literature has long-standing traditions despite the fact that the national literary criticism as an independent branch of literary studies only forms in the beginning of the $20^{\text {th }}$ century. After the revolution of 1905 some possibilities for the discussion of important issues of socio-national, spiritual-cultural renewal, evolution of arts including that of literature opened up. The emergence of the national press, publishing houses set out the conditions for formation and development of literary criticism and national literature as a whole alongside with the national philosophical and esthetical thought (Khayretdinova, \& Karabulatove, 2012; Sayfulina, et al., 2013). We come across images-symbols in the national mass media, which are characteristic for the Tartar ethnical and religious cultures, which were to highlight the spiritual connection with the people (Khayretdinova, \& Karabulatove, 2012 (a); Karabulatova, 2013), and provide for the lasting identification of an individual with the ethnos despite the unifying processes in the context of globalization and migration (Karabulatova, 2013; Tukay, 2006).

The beginning of $20^{\text {th }}$ century is being defined as a period of emerging Tartar scientific thought, theory of literature, serious discourse about the literary terminology and concepts, as well as the time of achievements in this area. And literary criticism plays its role in this process whereby the cultural landmarks of the East and the West have a significant influence; their juxtaposition finds its reflection in the resolution of the theoretical issues of the Tartar literary criticism. The authors dwell for the first time upon the emergence of the Tartar terminology in literary criticism in relation to the lingvocultural aspects and demonstrate how the Tartar terminology evolved having sprung from the Arab terminology system and arrived at the European terms. This work is devoted to the research of the evolution of the Tartar literary criticism, development of the national scientific-critical thought. Also we uncover the patterns of the change in the historical-literary periods in Tartar literary study in the context of the global literary science, which determines the authenticity and novelty of this work.

\section{Methods of Research}

In order to analyse literary and critical discourse of the time we turned to the archives, newspapers of the beginning of the $20^{\text {th }}$ century; to the articles published in the magazines of the time. First of all this was a descriptive method which was centred on accumulation of data with further monitoring and analytical screening. Having evolved over a very short period of time as an independent branch of the national literary science, the Tartar literary criticism takes on a function of tracing and assessing the literary process as a whole, determining the patterns of its development and new trends in the literary movement. As any science literary criticism having stepped on the literary-cultural scene and having claimed independent role proceeds from establishing the subject, object of its study and assessment, from defining its role in the literary process and its social function. The act of interpreting literary concepts to a large or small degree of social relevance is 
seen by the researcher as the basis of the literary-critical work, and category "method" gains the status of the gnoseological value. In the $20^{\text {th }}$ century with the publication of works by M.Heidegger and G.Gadamer on hermeneutics and having arisen from methodology smoothly moves into ontology (Govorukhina, 2009; Barthes, 2007; Culler, 1983; Thorpe, 2000).

In the beginning of $20^{\text {th }}$ century two terms are used to define this type of literary art in the Tartar literary circles: criticism and intikad. According to hermeneutics-ontological concept the literary critical work is understood as an act of (self)interpretation claiming general validity and formalized in the further act of text-generation and is undoubtedly broader than the act of interpretation of the literary concept. While analysing numerous materials devoted to the issues of Tartar literary criticism, the fact that R.Fakhrutdinov, N.Dzhamal, N.Gasryi, M.Ukmasi, et al. use primarily the Arabic term "intikad" (Intikad Tamadun, 2012, p.11) is of interest. At the same time renowned Tartar authors such as F.Amirkhan, G.Ibragimov, G.Tukay, G.Battal, G.Sagdi, et al. having referred to the term "intikad" in their certain works, gave their preference to the term "criticism" further down the track. And at a later stage the Tartar literary scientists used the term "criticism" more widely than "intikad"; " Even though in the Arabic language the usage of "intikad" is the correct expression, but "criticism" should be used instead, as it has been widely accepted and used here" (Sagdi, 1912, p.4).

The classification of the methods of the Tartar literary criticism has the following type: analytical-oriented, pragmatic-oriented (the first denote the dominating components) and analytical-pragmatic. To find the dominant is possible based on the following. The author's summary of the goal/task is a unique mental nuclear which becomes the "flesh" of the critical literary piece. As a rule the pragmatic aim is not verbalized by the critic, but at the same time its presence in the structure of the goal is indispensable. In this case a rare occurrence of verbalization would be significant (perhaps even pivotal) in determining the dominant. The determination of the analytical goal/task is not an objective indicator of the value of the analytical component in the light of verbalization of this particular goal with active realization of the pragmatic goal. It is rather the variety of methods, which serve to realize the pragmatic component of the goal. These methods are singled out in every literary-critical text and therefore they can't be an indicator of this or that component being dominant in the text. At the same time their variety within one article gives us an indication about the conscious orientation of the author towards the pragmatic goal. The literary critical evaluation is by all means one of the components of the literary critical work. The fact that it is present though is not an indicator that one or the other component of the method is dominant. At the same time the plurality of evaluations within one text, high degree of expression, indication of the criteria of evaluation without any doubt point towards the significance of the pragmatic goal "to impart upon the reader its own evaluation scale", "to infect" the reader with one's own positive/negative/neutral evaluation. Such are for example literary critical works of G.Ibragimov (1916), Nasyip (1911), G.Tukay (2006). The communicative status of the recipient acquires a special status and plays a special role. In pragmatically oriented texts the reader plays an active role of a participant in the discourse about a literary work/phenomenon, in analytically-oriented his role is that of a "silent confident". The emotional/expressive degree provides for the involvement of higher numbers of recipients. The high degree of expressiveness can serve as an additional (but not compulsory) indicator, that the pragmatic component of the method is prevalent. And vice versa detachment, emotional "scarcity" of views points towards the presence but not expressed pragmatic component. The analysis of the literary-critical articles, that came out in "fat magazines" of the early $20^{\text {th }}$ century enables us to replenish the description of each method based upon the above named reasons.

The analytical-orientated method realizes one-sided pragmatic goal of the critic, which is to convince the reader in the veracity of one's own opinions. He uses the tools of the special scientific methods. The scientific orientation serves a pragmatic function and imparts a feeling of the veracity of the opinion upon the recipients. The critic doesn't have to resort to the fully fledged system of pragmatic methods. As a rule this methods does not "encroach" upon the intellectual or value systems of the recipient. The status of the author who has chosen this strategy (researcher) by far comes down to verbalizing the stages of interpretation of the literary phenomenon. The core message of the pragmatic-oriented critical narration is to expose and to bring to the norm. Very often a pragmatic component of the goal would overcome the boundaries of the context (to convince in the accuracy of one's own concept/evaluation/point of view) and impacts upon the mental attitude of the recipient.

On the whole the literary criticism as so precisely formulated W.H.Auden shows human relationship with the society and the God (Auden, 2014). We believe that the most common model for critical work has the following; over the level of text interpretation and its evaluation there is a level of gnoseological and communicative tasks which predetermine the programme of interpretation and which gravitates either to the Oriental or to the European scientific school of thought. Combination of hermeneutic-ontological and communicative approaches enables to impose the methodological attribute both onto the primary act of the critique work, as even the primary perception by the critic of a literary phenomenon is geared towards the recipient, as well as onto the further act of text generation and realization of a 
tentative goal/task.

What is significant for our understanding of the method of literary critical work is that it embraces all components of the structure; literary phenomenon - critic - critical text - recipient. The general strategy which organizes the whole process of interpreting and evaluating a literary phenomenon and its expression in the process of text generation is being aligned by a critic depending on the communicative and interpretational (in ontological sense) goal. This interpretation of the method envisages a different depth of interpretation, different quality of self-presentation, different degree of explicitness of the pragmatic impact. The methods of humanitarian scientific cognition doesn't use critique in the "pure form", rather the works are reassessed depending upon the goal orientation of the critiquing author.

\section{Results}

The screening of the Tartar literary criticism of the beginning of the $20^{\text {th }}$ century shows that over this period of time there occurs the establishment of the terminology in the Tartar literary criticism, which borrows a lot both from the Oriental (Arab) and European cultures. Literary criticism is a complex process of (self)interpretation, whereby two acts of understanding blend - primary (an instant insight of the truth of being) and secondary (verbalization of that that was understood, expression in words and unfolding of it as interpretation, reflected memory). The secondary act according to M.Heidegger is methodological (Heidegger, 1993). In 1916 magazine "Shura" published monographic article by R.Fakhrutdinov "Intikad ve Tegan (sugu hurlau) (Criticism and Insult, 1916), where the author talks about the origins of the national critical thought, its forms and patterns of evolution, types of critique and requirements based upon the Islam culture, religious dogmas. The author starts his article from deliberation about the origins of the word critique, establishing its semantics, on how it came to be part of the scientific and practical circulation, and goes on to talk about the words with the same root or semantically close words. The author reminds about the fact that to relay this meaning the Arab people have used the word "nakade" since times immemorial. If the term "intikad" goes back to the word "nakade", then the term "tenkiyte" (criticism) has no explanation. The scientist writes: "The dictionaries define "nakade" as being used in speech while differentiating counterfeit money from the real." (Fakhrutdin, 1916). The use of the word "criticism" Fakhrutdinov explains by the influence of time. "As of to-date the term "tenkyite" is widely used instead of "intikad". The meaning of the word "intikad" also denotes differentiation of a correct thought from the false" (Fakhretdin, 1916). In his own work as a literary critic the scientist prefers the term "intikad".

Some thoughts about the use of these terms in the scientific-theoretical discourse of the $20^{\text {th }}$ century, about their origins, meaning can be found in the work by G.Ibragimov "The Postulates of Literature" (1919): "The word tenkyit (criticism) originates from the word "nekyd". It was used in the meaning of "to differentiate real money from counterfeit" (Ibragimov, 1919).

In the literary critical thought of the early $20^{\text {th }}$ century there starts the exchange of views about peculiarities of certain types of literary critique, different trends characteristic of Tartar literary criticism are being set apart.

The work of literary criticism in relation to recommendations to a literary piece, description of its "positive" and "negative" aspects, assessment of "successes and failures" gives a momentum for national "izhabi" (positive) hem "selbi" (negative) critiscism" (Ibragimov, 1919). Identification of weak aspects of a literary work comes to the fore in order to help authors and also for others to avoid making the same mistakes.

A famous poet of the Tartar people and one of the founders of the Tartar literary criticism G.Tukay having returned from Uralsk to Kazan writes a well-known article "Criticism Is Necessary" (1907). In this work, where for the first time in the Tartar literary science there emerges an issue of the necessity of the literary critique, he describes the subject of the literary criticism and identifies its peculiarities. He determines the function of the literary criticism as "correct, objective identification" of positive aspects and shortcomings of a published work of literature (Tukay, 2006). A little bit later G.Battal proceeding from the thoughts by N.Livanov in his book "Textbook in the Theory of Literature" and having written his own text book "Theory of Literature" 1913 explained the term in Russian literary science and gives a definition of this term in his native language "Tentikai is a criticism, conclusion after something has been read, which gives an assessment to a piece of art be it a literary piece, music, i.e its positive and negative aspects are being discussed. In parallel subjectivity is being introduced into the literary critique. We are not just talking about a degree of subjectivity, which a humanitarian cognition envisages, rather it is the subjectivity, which plays the role of an argument in criticism. So now we can see how an impression from something read becomes the foundation for forming evaluation.

G.Ibragimov also considers literary criticism as one of the stand alone parts of the literary science and his views as to the nature of this type of the creative work are similar to those of G.Battal. He also comments that: "In literary science criticism is consideration and assessment of pieces based on certain criteria" (Ibragimov, 1919). The scientist notes that the term "criticism" is being used in two meanings. "In reality every deed, every khadis finds criticism from those who 
study this issue", the author comments wide usage of this term. Also he introduces new meaning into the term criticism, which is used up to this day: "In a narrow sense criticism is being understood as an opinion, evaluation of books, that came into existence in the modern literary scene" (Ibragimov, 1919). Literary scholar T.Gilazov has highly appreciated the role of G.Ibragimov in the formation of the Tartar literary criticism and thinks that "G.Ibragimov is one of the founders of the Tartar literary critique....well-respected and influential, known in the literary circles for his intelligence and depth of theoretical knowledge" (Gilazov, 2009).

The ideological-esthetical views of the Oriental culture play a certain role in the resolution of the theoretical issues of literary criticism. And in justifying a worthy role of the literary critical thought in the literary-cultural life, setting out the goals and tasks for the literary criticism of magazine "Shura", the above-mentioned R.Fakhrutdinov writes the article "Laudable Review or Critique", where he gives the following definition of criticism: "Upon careful reading of a book or a brochure, personally, with the serious view and setting aside friendships or otherwise with the author, having looked through the book after lengthy and careful consideration, we are called to give relevant evaluation as far as the triumphs and flaws of the author" (Fakhretdin, 1916). As far as previous authors are concerned here the requirements to those who perform critique include also attention, objectiveness and integrity.

Thus the periodicals of 1907-1910 on the whole resolve the questions of the role of literary criticism and the subject of its investigation. This time can be called as the period of emergence of Tartar literary criticism as a science. So the Tartar national criticism uses the method which demonstrates some signs of humanitarian method of cognition and which also has some peculiarities not common for the scientific set of techniques. Such a conclusion makes it difficult to define the typology of the literary criticism, which should not duplicate special literary methods and which must be looking for new classification criteria.

\section{Discourse}

The Tartar literary criticism as a science has its own historiography. The book of the scientist-educator S.Mardzhann "The Well of Knowledge on Kazan and Bulgars" (1885) makes the first attempt to explain the nature of this type of literary art. Before attempting to analyse and assess the book by Khusameddin Muslimi "The History of Bulgaria" (18 scientist gives his understanding of the term criticism: "Your humble servant having taken into consideration capabilities and time, takes on the task of exposing some erroneous ideas in some important issues, with the idea of warning, so that the reader having read the book would not acquire false opinions..." (Mardzhani, 1989).

At the same time in $1910^{\text {th }}$ the issues of defining and specifying goals and tasks of this type of literary art, relations between the critics, readers and writers, professional fulfilment in this field are still very current. This qualitative change is to do with coming to the literary arena of academically learned critics such as G.Gaziz, G.Rakhim, G.Karam, N.Khalfin, H.Karimov and Dz.Validi, who have gone through a secular education. Critics and authors use traditional notions of the world and Turkic-Tartar literature and express their view as to the role of criticism in the development of fiction and contemplate upon the role of the critic. For example M.Ukmasi compares the role of the critic with the process of "separating gold from semi-precious minerals, which distort the true value of the gold" (Ukmasi, 1911). It must be said that the scientific-theoretical thought of the time place literary critique as a means of boosting esthetical level of the national literature to the levels of European literature. "Thanks to the literary criticism there have been so many literary works created in the European world. In Europe when a book comes out both scientific and artistic it is assessed by the admirers of literature, (they say) the way the garden is the way the pay is, work determines tribute" (Ibragimov, 1919). Thus at this stage of its development the critics analyse the works of national literature in the context of Russian and European literature, view the ways of reviving its content and increasing the value of ideas and art form of the literary text.

Nadzhip Garsyi in his article "Our Literature Needs Critics" (Newspaper "I"/"country" 1913, 14 November), for example compares literature to a garden left without a gardener. "As much as in a garden the flowers would wilt without care, water, sun light and will be covered with the nettle, in literature the same without critique many talents would just waste away and their spot would be taken by mediocre people who would not enrich the art or the people" (Gasryi, 1913). It must be noted that criticism in the author's view is significant from the point of view of evolving the literary art, refining literary taste of the reader for the benefit of the people and the nation. He further refines his thoughts about literary criticism saying that "... it is the most important deed that propels further development of literature".

Further the critical thought goes on to contemplate upon the requirements to the criticism, the methods and techniques of criticism and types of criticism. We know that as different from the precise sciences, art including fiction is being perceived through emotions. As is being subtly noted by critic G.Sagdi that even the character of the reader, his mood plays a certain role in understanding and perciving a piece: "At the same time inadequate perception of beauty or flaws of a poem depends upon the mood (of a reader). Because (the mood) of the reader is not always the same. 
Therefore a poem that today influenced over us positively and was perceived by us as beautiful, tomorrow might not have the same effect and might not be perceived positively. And we (our soul) would remain in relation to this poem completely apathetic. Even though the poem is the same" (Sagdi, 1912). And so to understand and assess a piece there is a lot of room left for a subjective perception. In this relation and along with the question of whether the literary criticism is necessary for active, positive development of literature, there is also a question of requirements to the critics. Similarly G.Tukay in the above-mentioned article "Criticism is Necessary" proves the necessity of literary criticism and writes about requirements to a critic such as objectivity, integrity, responsibility; also he stresses that a critic must be an experienced, high spirited and creative person (2006).

As was mentioned before critical articles written in $1910^{\text {th }}$ are characterized by a broad range of issues at hand as well as high degree of requirements to the personality of a critic. The article "Methods of Criticism" by Dz.Nasip ("Zvezda") of $15^{\text {th }}$ of January 1911 permeates with the idea that literary criticism should serve homeland and the nation as a whole. Careful familiarization with the book to be discussed, its consideration from many points of view are in his view the main conditions of criticism. The author also points out the following and nonetheless important factors which should be taken into account while analysing a piece and clarifies his thoughts: "1) a literary work should portrait the theme of the homeland and the nation and protect their interests; 2) to evaluate success of a writer in presenting an idea, compositional structure of a piece; 3) to draw attention to the style of the author, to the language of a literary work" (1911).

The article by M.Ukmasi "Intikad" ("Criticism") is also written in the same vein. Both of these pieces primarily devoted to one issue - understanding the requirements to the criticism, are similar in their core to the role of the literary criticism. Whereby M.Ukmasi adds to the list the fact that the criticism must identify sophistication, poetical value of the language of an author while creating national pieces. Here he raises the issue of rearing a crop of literary critics. The author refers to the worthy critics as "diamonds" and acknowledges the fact that at present those were very few.

We know that from $1910^{\text {th }}$ in medrese schools Tartar literature is being taught as a subject. And there came out text books, where alongside the theory, history of the literature, some chapters were devoted to the literary criticism. In this connection G.Sagdi writes: "in Tartar medrese schools there started a movement of introducing Tartar literature into the school curriculum as a very important and necessary science. With the onset of teaching Tartar literature at schools and perhaps as a consequence of it criticism came to the fore of looking at literature and creative work of writer and poets. And the acceptance of criticism and its important role in social-literary life was acknowledged by all." (Sagdi, 1927). In order to bring the requirements to the criticism into a system G.Sagdi wrote in his book "Methods of Literature" about 8 requirements to the critique; impartiality, ability to think adequately, to be well-rounded as far as social sciences, history of the nation and its culture; careful familiarization with the theme and content of the literary work; to understand final goal of the literary criticism, be cool-headed, spiritually strong and emotionally balanced; not to be bound by burdens of copying; and to have a sound understanding of education and up-bringing (in school) in assessment of a text book. (Sagdi, 1927).

In the introduction of the above-mentioned article of R.Fakhrutdin "Criticism is Necessary" the author also gives deep understanding of criticism in the light of Islam. Therefore while defining the requirements to criticism he bases his discourse upon the human nature of Sharia law and its moral values. He established the causes which brought about one of the types of criticism "tagan", i.e. insults, accusations and humiliations. R.Fakhrutdin also explains the nature of the conditions of criticism. The scientist writes about eight conditions which must come to the centre of the criticism: 1 ) positive spirit in achieving a goal (in his opinion the deeds tuned on to positive outcomes are evaluated as good deeds in the Sharia law and they deserve gratitude and the initial impulse to insult a person while pointing out his drawbacks, to humiliate him in front of others, are in Sharia law an ill deed; 2) to understand the level (of ideas and of esthetical thought) of the work at hand, to be familiar with the issues; 3 ) to explain in the nutshell the drive of the article or piece of literature; 4) knowledge of the critic (in the area) should not be less than that of the author's (of the analysed) piece, article; 5) (critic) should not be against the freedom of thought; 6) he should proceed from his knowledge (intelligence) and (laws) of Sharia laws, spirituality and faith; have adequate perceptions (about the world); 7) (ideas of the critic) must be justified; 8) a critic should not conceal his name and be open (to the reader) (Fakhrutdinov, 1908). Thus what is significant here is that R.Fakhrutdinov proceeds from human norms and moral values as well as from the fundamental ideas of Islam culture, Koran.

The second school in defining the requirements to criticism finds its reflection in the work of G.lbragimov, G.Battal. The cause for a different, new approach in explaining the subject of the criticism, its requirements, etc., scientifictheoretical thought can be first of all their different perception of the world, secondly by the influence of European-Russian literary science and its achievements. Both scientists perceive criticism as one of the branches of the literary art, which requires logical proof to deliver a message. Furthermore they base their school of thought upon the following definition of G.Battal in his book "Theory of Literature" (1913), using the term of Russian literary science, requirements which should 
be used in assessment of a literary piece and refers to it as a "criterium": Criterium is the criteria and rules, used while critiquing literary work and pieces of art" (Battal, 1913). The scientist stresses that literary criticism is indeed scientific and looks at it alongside "scientific and philosophical books", therefore the requirements to the logical and analytical thinking come hand in hand with the rest of the requirement of the literary criticism.

In his work pertaining to the theory of criticism he talks about the peculiarities in the nature of the critiquing text and its place is being seen between the literary and scientific texts. And as different from a literary text there is no ambiguity and when compared to the scientific text it lacks scientific precision.

G.Battal identifies the following criteria to the literary criticism; the criticism must comply with the theoretical postulates and rules; a literary work should be assessed based upon the requirements of the modern science and theory of arts; the attention must be given to how main and subordinate ideas of a book intertwine; full delivery of the idea of a piece; evaluation of consistency of an idea and composition of parts of a piece according to its main idea; analysis of the style of the literary piece according to the relevant theory and rules (Battal, 1913).

G.Ibragimov published his pursuits in the area of literary criticism in a separate chapter of his work "Laws of Literature" (1919). He aspired to create a scientific foundation for the criticism and calls for "rules and laws" instead of "conditions of literary criticism" or "requirements to criticism". When speaking about the assessment of a literary piece he introduces term "mizan" (criterion) into the scientific definition; "while assessing a literary piece or analysing and evaluating all literary pieces by one author the rules and ideas used by a critic to find positive and negative sides are referred to as mizan or criteria of the criticism or "criteria" Ibragimov, 1919). The discovery of "the inner nature of the piece at hand", understanding the main idea with the help of the language, style, content, relation to real life G.Ibragimov defines as the aspects which must have evaluation through definite mizan-criteria. Saying that the analysis must be objective, the writer compares criticism with the double edge sword; "Criticism must be like a double edge sword. If one edge of it is excavating for diamond in the narration the other edge is clearing the windfall (literally - from rubbish)" (Ibragimov, 1919).

In 1910 G.Gubaydullin who, back then started to write theoretical critical insightful articles, publishes a polemic article "In Young Literature" - "Young Hearts". This article is devoted to the namesake by G.Ibragimov and notes that this type of literary art leaves a lot of room to subjectivity and personal opinion and he ventures a term "subjective criticism" (Zakirzyanov, 2011).

R.Fakhrutdinov was taking into account what were the conditions when a literary work received critique, its spirit, views of the critic, and he singles out two types of criticism; truthful and authentic and Tegan - insulting, humiliating. And proceeding from the European theory of literary criticism, he contemplates upon the nature of the "truthful" literary criticism. He stresses that it requires "cool intellect, depth of knowledge and integrity, sophistication, upbringing and culture." As it is seen from the author's definition of "truthful (authentic) criticism" he doesn't proceed from the scientific ground laws of evaluation and analysis of a literary piece, rather he grounds it into the common values of humanity and moral values. It is clear that he considers "truthful" criticism the criticism which is true from the point of view of virtue, true in the light of Sheria laws and which in its nature opposite to tagan (random insults as criticism). R.Fakhrutdinov winds up his article again with the definition of the nature of "tagan", which takes place when the fundamental requirement to the criticism is being breached, namely objectivity and impartiality. Tagan doesn't promote literature. Also F.Fakhrutdinov stresses that this term is ubiquitous as a term in Europe and not just in Islam countries. The scientist points out to the main causes of "tagan" which is in nature subjective, partial and hostile; lack of education and in-sight; casting an opinion towards a person you are initially hostile towards; self-centeredness and greed.

\section{Conclusion}

The Tartar literary scientists defined the subject of the literary criticism under the influence of two cultures and tow ideologies. And while G.Ibragimov, F.Amirkhan, G.Tukai, G.Battal, M.Ukmasi show the influence of the Russian literary science, which emerged under the influence of Latin and Ancient Greek civilizations, R.Fakhrutdin, G.Sagdi work on the basis of the Oriental theoretical-literary thought, which has had a huge impact over the Turkic-Tartar world over the centuries and formed general esthetical and moral values. Even though Tartar scientists do attempt to develop terminology for the national literary science including literary criticism, however they were unable to resolve this issue without resorting to the achievements of the Eastern and Western cultures.

Literary criticism which really grew out of "infancy" when F.Amirkhan, G.Tukay and G.Iskhaki created their works, starts to evaluate a literary piece from the point of view of ideological-esthetical norms as well as from the point of view of artistic merits. The critical thought of that period takes on the function of the theory of literature, which just made its first steps, i.e. the function of critical assessment of the new tartar literature and the direction of its further development. "It 
performs a direct function valuable for forming the theory of literature - it links the theoretical thought with the national literary movement and with separate literary works. It performs the function only literary criticism can perform" (Zakirzyanov, 2011, p.44).

It is impossible to define the system of consistent methods of influencing over the recipient which Tartar critics of the beginning of the $20^{\text {th }}$ century use. In the pragmatically oriented articles published in the early $20^{\text {th }}$ century there would be an accord with the opponent of the whole however divergence of views in details of principle importance; reference to an authority; reference to the religious, esthetical, national values as a way of getting negative feed-back from the recipient; finalizing the views of the opponent to the logical resolution; emphasizing simplicity of one's own conclusions and hence their obvious nature; breaking down the concept of the opponent into a pattern. The analytical component of such texts serves to realize pragmatic goal.

The literary criticism of this period goes back to an author's views towards the requirements of the time; the connection of a literary piece with the modern reality, national life and reflection of true picture of life is perceived by the critics as one of the main laws.

The work of the founders of the Tartar realist school of critic such as F.Amirkhan, G.Iskhaki, G.Kamal, et al. form also the main principles, means and ways of the literary criticism. They also raise the questions of national ethos and national fiction literature. The possibility of reflection real life is most complete and true through live and life-like personages, authentic character types becomes the focal point of the critical thought of that period. Proceeding from the national pictures, phenomena that found expression in the literary works of art, the critics talk about general and individual literary images, about social types.

During this period the Tartar literary criticism is based upon the views of the cuturological-historical school that was founded in the European-Russian literary science and which promotes development of the realistic school of literary criticism. However the term "realistic criticism" is not part of the scientific circulation and only a little bit later in 1920 G.Sagdi noted when he analysed the work of F.Amirkhan: "that F.Amirkhan has always been a realistic critic of the Tartar bourgeois class from day one of his literary work. He possessed the "precision of an eagle" rather than a representative of one of the art form - the literary art" (Sagdi, 1927).

Creation of another school of critical thought alongside realistic was romantic criticism and this became one other achievement of the Tartar literary thought of the $1910^{\text {th }}$. Esthetical (romantic) criticism and pursuits of scientists in this direction was formed under the influence of the psychological Russian-European literary science. Some of its concepts find their expression in the literary works of G.Iskhaki, Dz.Validi, N.Dumavi. And the concept of romantic criticism finds it theoretical expression in the article of G.Ibragimov "A Couple of Words In Relation to Publication of the Album" (1915). T.Gilazov writes about the role of G.Ibragimov in developing the new paradigm in the Tartar literary science namely of romantic criticism (Gilazov, 2013).

The process of emerging genres evolves alongside two cultures as well. In the middle ages the Turkic-Tartar scientific critical thought having formed under the influence of the classic Arab and Persian cultures makes an attempt to form its own genres. At his time there used to be a tradition of giving an opinion of the works of contemporary authors within a framework of one's own poetic literary piece. There used to be very common such phenomena as "sherekh" (clarifications), "khashnya" (writing on the book margins) as well as "tegziya" (obituary), which survived to this day. All of those go back to the cultural and historical layers of our predecessors. The last quarter of the $19^{\text {th }}$ century saw the appearance of such genre of criticism in the Tartar literary critical thought as related to the Russian-European culture as article and review. In particular K.Nasyri publishes his first reviews, articles, news in the newspaper "Translator", which was published by I.Gasprinskiy in Bakkhchisarai.

The early $20^{\text {th }}$ century also saw active development of the genres of literary criticism. The issue of genres in the scientific literary thought was already discussed as a theoretical issue. And the works of such authors as F.Amirkhan, G.Tukay, G.Ibragimov, Dz.Validi, N.Khalfin write in different genres of the review; mono-review, overview review, short review, abstract, review article, etc.

G.Ibragimov in his book "The Rules of Criticism" writes an article and lists retraction as a genre of the literary criticism. He goes on to define a review: "Articles that are published in the periodicles and which give a brief description of an opinion about a literary piece, concert, play, without going into much proof are referred to as a review" (Gilazov, 2013). A genre Reddiya in his view gives "answers as far as "negative" criticism of the publisher (author of a piece) or somebody else". Furthermore he mentions that in Russian literary science this genre is being referred to as "anti-criticism". And in $1910^{\text {th }}$ the genre of the article becomes more prominent due to the development of the analytical thought in the Tartar literary criticism.

In the beginning of $20^{\text {th }}$ century the following terms, that were borrowed from the Eastern world, were widely used "tekriz" (review), merasele (letter), mekhabere (news). However these names of the genres did not pass the test of time 
and are not part of the scientific language any longer.

In the early $20^{\text {th }}$ century the Tartar literary criticism lives through a time of evolution linked to the shift in the gnoseological points of reference and accordingly the methods. It is very evident in the critical texts which could by united by a common subject "social consciousness and its research in the art form". As far as the results of the research show the variety of the genres of criticism can be traced back to the work of F.Amirkha, G.Tukay, G.Ibragimov, Dz.Validi. And in $1910^{\text {th }}$ and having been influenced by the Eastern classics, Russian and European literary cultural environment there emerges a whole system of literary criticism genres: various forms of reviews and articles such as mono-review, reviewarticle, flagship articles, topical articles such as satire, literary portrait, annual review, letter, literary-critical dialogue, obituary, news etc.

And it is not just the moral and intellectual views that become of value, but also intellectual-psychological. It is noteworthy that the Tartar literary criticism doesn't just cover some parts of the society, rather it writes about the overall state of the consciousness and self-consciousness. In our view this is to do with the peculiarities of the "communal" consciousness of the Turkish people. The analytical strategy is being geared towards the search and analysis of the "symptoms" Perhaps, it is directly related to the claim of the criticism to be leading and guiding a reader as someone possessing the knowledge to do so. Now it identifies rather with the analytic of an encyclopaedic level.

So in the beginning of the $20^{\text {th }}$ century the Tartar literary criticism having experienced the influence of the Arabic, Persian, Russian and European cultures is being formed as a finite esthetical system. The discourse about the various literary critical concepts forms its own direction for development; investigates the trends of development and patterns of Tartar literature and sets out its further development.

The observation over the general dynamics of the literary-critical method/strategy, its analytical component allows to come to general conclusions as far as communicative and epistemological situations and peculiarities of functioning of criticism. Over the $20^{\text {th }}$ century the circumstances of communication were changing accentuating the loss of an important component of the communication (real reader) (Ealeton, 2002; Culler, 2002; Bloom, 2002; Mattew, \& Bukharaev, 2000). Abrupt deformation of the communicative chain leads to a crisis and perplexity of the critic. By inertia does Tartar literary criticism continue to appeal to the mass consciousness; exposes myths, restores ideas about the esthetical and humanistic nor and simultaneously uses maximum of pragmatically oriented methods (pragmatic component in the method of this time is dominant) and it also actively re-builds its dialogue with the recipient (Matthew, \& Bukharaev, 2000). Furthermore the Tartar criticism adopts to the new communicative environment, resolves the issues of selfidentification and gradually the Tartar criticism re-orients from the mass reader on to a small circle of recipients (professionals in their majority). However it is the Tartar literary criticism that builds the foundation for further development of the Tartar literature and Tartar theoretical thought; these branches of the literary theory undergo quantitative and qualitative change having been conceived in the bosom of the literary criticism.

\section{Acknowledgments}

This work was funded by this subsidy allocated to Kazan Federal University for the state assignment in the sphere of the scientific activities.

\section{References}

Altan, M. (2003, December 2003). Cemil Kermencikli and the Crimean Tatar National Identity. International Committee for Crimea. Retrieved October 22, 2014, from http://www.iccrimea.org/literature/kermencikli.html.

Auden, W. (2014). Literary Criticism. Retrieved December 3, 2014, from http://www.enotes.com/topics/w-h-auden-61078/criticalessays/auden-w-h.

Barthes, R. (2007, April 22). Criticism and truth. Continuum. London: Bloomsbury Academic. Retrieved December 3, 2014, from http://ru.calameo.com/read/002705171060179114e50.

Battal, G. (1913). Nazariyate adabiya. Kazan: Omet.

Culler, J. (2002). Barthes: A Very Short Introduction. Oxford University Press.

Culler, J. (1983). On Deconstruction: Theory and Criticism after Structuralism. Cornell University Press.

Gasriy, N. (1913, November 14). Adabiyatybyz monakykiydka mohtaj. II.

Gilazov, T. (2009). Literary Reputation of Tukay in the Esthetical Concept of G.Ibragimov. News of the Volgograd State Teacher Training University, 10(44), 172-174.

Gilazov, T. (2013). The Literary Reputation of G.Tukay in the Scientific-Critical Thought of the First Quarter of the 20th Century. Philolgy and Culture, 3(330), 181-185;

Gyilazhev, T. (2008). Retsenziyalardan tagzinadarga: XX yoz bashi tatarp adabi tankiyte. Kazan: Tatar. kit. nashr. 
Zakirzyanov, A. (2011). Main Schools of Development of the Modern Tartar Literary Science (end. XX - beg. XXI). Kazan: Ikhlas. Ibragimov G. (1919). The Theory of Literature. Kazan: Daulat Publishing house, "Sabakh".

Karabulatova, I., \& Polivara, Z. (2013). Turkic and Slavs: bi-polylinguism in globalization and migrations (on an example of Tumen region). Middle-East Journal of Scientific Research, 17(6), 832-836. ISSN 1990-9233. C) IDOSI Publications, 2013. DOI: 10.5829/idosi.mejsr.2013.17.06.12263.

Karabulatova, I. (2013). The problems of linguistic modeling of new Eurasian linguistic personality in multilinguistic and mental environment (by example of onomasphere). Middle-East Journal of Scientific Research 17(6), 791-795. ISSN 1990-9233. ( IDOSI Publications, 2013. DOI: 10.5829/idosi.mejsr.2013.17.06.12262.

Kurakova, C. (2014). The Work of the Tartar Author A.M.Gilyazov in Evaluation of Soviet Critics 1960-1970-s - Evidence from the Novel "Three Acres of Land"). Philology and Culture, 2(36), 145-149.

Мәржани, Ш. (1989). Mostafadel-ahbar fi ahvali Kazan va Bolgar. Kazan: Tatar. kit. nashr.

Nasyip, Z. (1911, August 15). Criticism is Necessary ("Intikad ysullary"). Yoldyz.

Sayfulina, F., \& Yakupova, L. (2014). Literary Criticism in Magazine "Kazan Utlary" («Lights of Kazan»). Philological Science. Theory and Practice in 2 parts, Part I, 5(35), 153-156. Tambov: Gramota.

Segdi, G. (1912). Adabiyat ysullary. Orienburg: Vakyt.

Segdi, G. (1927). Bezda adabi tankyit' (Iktaberenen un yellygyna). Kazan: Beznen yul.

Tukai, G. (2006). Saylanma asarlar. Ike tomda. Part II - Makalalar, istaleklar, khatlar. Kazan: Tatar. kit. nashr.

Ukmasi, M. (1911, July 7). Intikad. Yoldyz.

Fakhretdin, R. (1916). Intikad va tagan: intikadmy? tankyit'me? Intikadnyn faydasy. Shura, 16, 391-393.

Fakhretdin, R. (1916). Intikad va tagan (intikadnyn shartlary). Shura, 17, 410-412.

Fakhretdinov, R. (1908). Takriz va intikad. Shura, 1, 24-26.

Sibgatullina, A. (2014). Metamorphoses of Panegyrical Genre in Tatar Literature. Tatarica. Retrieved December 3, 2014, from http://www.academia.edu/6471687/tatarica_literature_metamorphoses_of_panegyrical_genre_in_tatar_literature.

Matthew, D., \& Bukharaev, R. (2000). Historical Anthology of Kazan Tatar Verse. Voices of Eternity. Richmond, Surrey: Gurzon Press.

Sayfulina, F., Karabulatova, I., Yusupov, F., \& Gumerov, I. (2013). Contemporary issues of textual analysis of Turkic-Tatar literary monuments of Western Siberia. World Applied Sciences Journal, Issue 27 (Education, law, economics, language and communication), 492-496. ISSN 1818-4952. @ IDOSI Publications, 2013. DOI: 10.5829/ idosi.mejsr.2013.27.elelc101.

Sayfulina, F., \& Karabulatova, I. (2014). European studies of barabin tatar folklore: the role of investigations of the german scientist V.V.Radlov. Retrieved December 3, 2014, from http://www.lifesciencesite.com/lsj/life1109s/021_25131life1109s14_116_119.pdf.

Khairetdinova, A., \& Karabulatova, I. (2012). The Specifics of Functioning of Nominative Units of Ethno-Linguistic Space (on the Material of the Tartar Language). Bulletin of the Kemerovo State University of Culture and Arts, Kemerovo, 2(15), 56-62.

Khayretdinova, A., \& Karabulatove, I. (2012a). On the Place of Informonives (nominative unit of mass media) in the modern EthnoLingvo-Information Space (Based of the Materials of the Tartar Language). Scientific Review, Moscow, Issue 2, Part "Linguistics", 1, 42-50.

Intikad Tamadun (2012). Moscow: Onix.

Govorulhina, Y. (2009, November). The Method of Modern Literary Criticism. Moscow: Philology. Retrieved December 3, 2014, from http://sun.tsu.ru/mminfo/000063105/333/image/333-010.pdf.

Eagleton, T. (2002). Marxism and Literary Criticism. Routledge.

Bloom, H. (2002). The Western Canon: The Books and The School of the Ages. Routledge.

Frye, N. (2000). Anatomy of Criticism: Four Essays. Princeton University Press.

Thorpe, J. (1990). Principles of Textual Criticism. Huntington Library Press.

Haidegger, M. (1993). Overcoming Metaphysics. Martin Haidegger "Being \& Time". Moscow: Publishing House "Republic". Retrieved December 3, 2014, from http://philosophy.ru/library/heideg/met.html. 